\title{
A cut above: A guide to improving due diligence in garments and footwear supply chains
}

Written by: Juliet Lawal, OECD Directorate for Financial and Enterprise Affairs

Last update: 2 March 2020

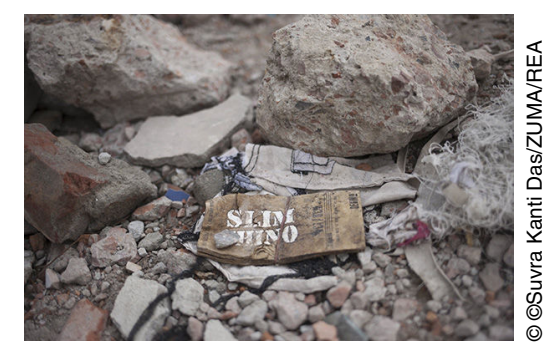

A cut above: A guide to improving due diligence in garments and footwear supply chains I Image for: A cut above: A guide to improving due diligence in garments and footwear supply chains

\section{Supply chain management is a tough challenge for global companies. A new OECD guidance can help them get it right.}

The collapse of the Rana Plaza, a commercial building and garment factory in Dhaka, Bangladesh, on 24 April 2013, claiming some 1,130 lives and injuring thousands more, brought global attention to the risks of severe adverse impacts in manufacturing and the widespread habit of cutting corners to keep production costs down in what is a tough global garments trade. There were outcries, on all sides, among workers, consumer groups, charities, governments and businesses too, about shoddy construction. Local rules and business practices came under scrutiny, with international brands and their customers in rich countries getting the brunt of the blame. The disaster was a jarring reminder of the need to strengthen the responsible business practices of such companies across their entire global supply chains.

Supply chain management is one of the toughest challenges companies face, particularly those in the garment sector. While government policy and international co-operation can help push for improvements, there is still a 
reliance on global firms to improve their approaches and act as vectors of higher standards of work and environmental care in the countries they invest in.

The OECD Due Diligence Guidance for Responsible Supply Chains in the Garment and Footwear Sector is a key tool to help brands and retailers observe standards of responsible business conduct in garment and footwear supply chains. It sets out practical ways to help businesses avoid potential negative impacts of their activities and their supply chains. It aims to bolster policy efforts to strengthen confidence between enterprises and the societies in which they operate, and complements both the due diligence recommendations contained in the UN Guiding Principles on Business and Human Rights, and the ILO's Declaration on Fundamental Principles and Rights at Work.

The fruit of a multi-stakeholder process with representatives from business, trade unions and civil society, as well as building on reports from the national contact points on responsible business conduct and feedback from engagement by OECD and non-OECD countries, this guidance seeks to encourage companies to operate and source responsibly in the garment and footwear sector. The commitment to responsible business conduct within a company applies to sourcing and subcontracting, and extends to business partners, consultants, licensees and anyone connected to the company via its supply chain.

Collaboration can be an effective way forward, for example, with trade unions or multistakeholder initiatives, but companies should ensure that those collaborations are effective and aligned with due diligence expectations. This alignment should also be assured among different internal departments, to ensure that the company is singing in unison with regard to their efforts to implement responsible business conduct in their supply chains, particularly those reviewing supplier environmental and labour performance and those placing the orders. This also presupposes good and well-communicated information systems, and probably a clear supply-chain mapping as well.

For the garment and footwear sector, the OECD Guidance highlights risks to watch out for, such as child labour and forced labour, corruption, health and safety issues, hazardous chemicals, and greenhouse gas emissions, while calling on companies to focus their efforts where risks are most severe. It devotes sections that look at these in some depth.

Crucially, companies should incorporate such due diligence into decisionmaking, including if it is launching a new product or is expanding to a country with a questionable human rights record. Another recommendation the OECD Due Diligence Guidance for Responsible Supply Chains in the Garment and Footwear Sector calls for is that companies know the harmful risks of both their own products and operations. This may seem obvious, but there may be visibility issues-perhaps the enterprise is sourcing from several countries, or with complex components. The OECD Guidance takes readers through some risk factors, 
classifying them according to scale, scope and the extent to which harm may be remediable. It points out that periodic scoping can help identify such issues and acting hand in hand with stakeholders can help resolve them. In fact, engaging with suppliers more generally, to get to know and understand them, is encouraged, while consolidating suppliers might also be a way forward for some.

In short, responsible business conduct is a constant process that requires oversight and commitment. Through our work and our collaboration with stakeholders, the OECD Due Diligence Guidance for Responsible Supply Chains in the Garment and Footwear Sector can help ensure that people's lives, their wellbeing and their welfare are treated with the utmost priority in all kinds of global investment decisions, and in particular in sectors as exposed and sensitive as garment and footwear.

\section{References}

OECD (2018), Responsible Supply Chains in the Garment and Footwear Sector, OECD Publishing, Paris http://dx.doi.org/http://dx.doi.org/ 10.1787/9789264290587-en

http://www.oecd.org/industry/inv/mne/responsible-supply-chains-textilegarment-sector.htm http://www.oecd.org/industry/inv/mne/responsiblesupply-chains-textile-garment-sector.htm 